\title{
Phomopsis amaranthicola and Microsphaeropsis amaranthi Symptoms on Amaranthus spp. Under South Texas Conditions
}

\author{
Patrick J. Moran, USDA-ARS, Beneficial Insects Research Unit, Weslaco, TX 78596; and Allan T. Showler, \\ USDA-ARS, Integrated Farming and Natural Resources Research Unit, Weslaco, TX 78596
}

\begin{abstract}
Moran, P. J., and Showler, A. T. 2007. Phomopsis amaranthicola and Microsphaeropsis amaranthi symptoms on Amaranthus spp. under south Texas conditions. Plant Dis. 91:1638-1646.

Temperature, humidity, weed species and age, and inducible responses in the host are factors that could limit the efficacy of fungal bioherbicides. The influences of these factors on the efficacy of the fungal bioherbicides Phomopsis amaranthicola and Microsphaeropsis amaranthi against Palmer amaranth (Amaranthus palmeri), smooth pigweed (Amaranthus hybridus), and redroot pigweed (Amaranthus retroflexus) were investigated in greenhouse and field studies under south Texas conditions. Despite plants being given an initial dew period, the bioherbicides, applied individually or in combination, did not cause mortality on any pigweed species in greenhouse or field environments. In greenhouse experiments, fewer than 5\% of the leaves in six- to eight-leaf A. palmeri plants developed necrotic lesions within 2 weeks after bioherbicide treatment and only $8 \%$ or fewer of the plants developed stem lesions. Disease incidence was significantly higher in A. hybridus and A. retroflexus, with as much as $94 \%$ of leaves developing necrosis and $95 \%$ of the plants having stem lesions. New leaf production was reduced by biobherbicide treatment in A. hybridus. Combined-pathogen inoculation caused leaf and stem lesions on mature (13 to 36 leaves per plant) $A$. hybridus and $A$. retroflexus. Summer and fall field inoculations with $M$. amaranthi on A. hybridus and A. palmeri produced disease incidence levels similar to or higher than those in greenhouse tests. Infection of A. palmeri by P. amaranthicola increased the peroxidase activity level nearly twofold compared with the controls. Neither pathogen influenced leaf free amino acid content. The high temperatures and low humidity of south Texas and interspecific variation in resistance, possibly linked to peroxidase induction, limited the efficacy of these bioherbicides.
\end{abstract}

Additional keywords: biological control, cotton weeds, Lower Rio Grande Valley of Texas

Native fungal plant pathogens have shown promise as bioherbicides when applied inundatively against weeds in crops $(2,10,11)$, but ambient temperature and humidity conditions that favor fungal infection $(13,30,38,44,46)$ might not exist in all regions in which the targeted weeds require control. In addition, bioherbicide disease development may vary according to weed age $(19,31)$ or species within the host range $(29,34)$, limiting efficacy in mixed weed infestations (15). Adjustments in inoculum dose $(13,15$, $23,31,33)$, formulation $(3,7,12,19,35,37$, $40,49,50)$, humidity (29), and the seasonal or diurnal timing of inoculations, as well as application of multiple pathogens $(9,29)$, can all increase bioherbicide efficacy, but may not be practical in all regions and crops.

Corresponding author: P. J. Moran

E-mail: Patrick.Moran@.ars.usda.gov

Accepted for publication 27 July 2007

doi:10.1094/PDIS-91-12-1638

This article is in the public domain and not copyrightable. It may be freely reprinted with customary crediting of the source. The American Phytopathological Society, 2007.
Pigweeds (Amaranthus spp.) are agronomically deleterious in the United States and Europe (8) and can reduce yields of cotton and other crops by competition $(14,36)$ exacerbated by rapid growth and copious seed production $(18,39)$. Nine Amaranthus species occur in the Lower Rio Grande Valley of south Texas, (32), including Palmer amaranth (Amaranthus palmeri S. Wats.), redroot pigweed, (Amaranthus retroflexus L.), and smooth pigweed (Amaranthus hybridus L.). Palmer amaranth is the most damaging species regionally and grows more rapidly than other Amaranthus spp. (39). Although synthetic herbicides are often effective against $A$. palmeri $(6,14)$, resistance exists to dinitroanilines, acetolactate synthase (ALS) inhibitors, photosystem II inhibitors, and glyphosate (17) and is becoming increasingly prevalent in $A$. retroflexus, $A$. hybridus, and other pigweeds $(20,22)$, creating a need for alternative control approaches $(5,8,11)$.

Two necrotrophic fungi, Phomopsis amaranthicola Rosskopf, Charudattan, Shabana, \& Benny and Microsphaeropsis amaranthi Heiny \& Mintz (Ell. and Barth.), target Amaranthus spp. (23,24,29, $33,34,44)$. P. amaranthicola has been patented for Amaranthus control (U.S. Patent
Nos. 5510316 and 5393728). In greenhouse and field tests in Florida and Illinois, 90 to $100 \%$ of A. palmeri, A. hybridus, and $A$. retroflexus seedlings developed leaf and stem lesions and as much as $83 \%$ of $A$. palmeri and $100 \%$ of A. hybridus and A. retroflexus were killed within 2 to 8 weeks $(29,33,34)$. Formulation of $P$. amaranthicola with surfactants, humectants, and other components increased efficacy $(25,29,33)$. Symptoms and mortality differed among pigweed species (34), between greenhouse or field environments $(29,44)$, across field trials with varying ambient humidity (33), and declined in seedlings having more than six leaves (24,35). Mortality and dry weight reductions occurred at moderate doses $\left(\leq 1 \times 10^{6}\right.$ conidia per $\left.\mathrm{ml}\right)$ $(24,35,44)$ when a dew period of $12 \mathrm{~h}$ or more was provided after inoculation, with temperatures between 20 and $30^{\circ} \mathrm{C}$ $(30,35)$.

No information is available on the efficacy of these bioherbicidal fungi in south Texas, where environmental conditions differ from regions where $P$. amaranthicola and M. amaranthi had been previously evaluated. Average daily maximum and mean temperatures between April and October in Weslaco, TX are $2.4^{\circ} \mathrm{C}$ higher than in Gainesville, FL and $8.6^{\circ} \mathrm{C}$ higher than in Urbana, IL, and total rainfall in Weslaco during these months is only 59 and $69 \%$ that of these two prior testing locations, respectively (28). This study evaluated symptom development in $A$. palmeri, A. hybridus, and $A$. retroflexus infected with $P$. amaranthicola and $M$. amaranthi under the relatively hot, dry conditions of south Texas.

Among the biochemical defenses induced in plants following infection, peroxidases can strengthen cell walls, are involved in signaling in response to pathogen infection (47), and may reduce bioherbicide efficacy when they are induced in weeds (1), but no information about the peroxidase activity level is available for pigweed bioherbicides. Changes in nutritive resources such as protein and free amino acids (FAAs) could influence pathogen growth (16), moderate plant stress (42), and alter the suitability of pigweeds for insect herbivores $(26,41,42)$. The effects of pathogen inoculation on these defense and stress indicators in pigweeds were therefore also examined in this study. 


\section{MATERIALS AND METHODS}

Temperature and relative humidity measurement. Greenhouse experiments were conducted at the USDA-ARS Kika de la Garza Subtropical Agricultural Research Center, Weslaco, TX. Temperature and relative humidity $(\mathrm{RH})$ data were obtained hourly, 24 hours a day, with an HOBO H8 meter (Onset Computer Co., Bourne, MA). Field experiments were performed at the USDA-ARS Rio Delta Research Farm, Monte Alto, TX $\left(26^{\circ} 25^{\prime} \mathrm{N}\right.$, $\left.97^{\circ} 57^{\prime} \mathrm{W}\right)$ in a Willacy fine sandy loam (fine-loamy, mixed hyperthermic Udic Argiustolls). Temperature and $\mathrm{RH}$ data were obtained hourly, 24 hours a day, with a Vaisala Model HMP35AC (Wescor Inc., Logan, UT). In both greenhouse to field and field season comparisons, daily natural dew periods were determined by summing the hours per day during which RH was $\geq 95 \%$. To compare greenhouse and field conditions, readings were taken during a 78-day period from 3 September to 19 November 2005. To compare summer and fall field conditions, data were collected from 1 August to 30 August and from 16 November to 15 December in 2003 and 2004 and were combined between years.

Humidity data were arcsine square root transformed. Hourly temperature and $\mathrm{RH}$ collected from 3 September to 19 November 2005 were compared between greenhouse and field environments with repeated-measures analysis of variance (ANOVA) using SAS PROC MIXED Version 9.1 (SAS Institute, Cary, NC). Maximum daily temperatures were compared using $t$-tests (PROC TTEST) with Satterthwaite approximations. Average daily and maximum temperatures and average humidity were also compared in a subset of the data (from 3 to 30 September 2005) that reflected summer conditions typical of most greenhouse experiments. Average greenhouse and field temperature and humidity between 2000 and $0900 \mathrm{~h}$ were also compared using $t$-tests. This 13 -h period was selected on the basis of past studies $(35,44)$ demonstrating that an initial dew period of $12 \mathrm{~h}$ or more was sufficient to produce symptoms, but that high nighttime ambient humidity and moderate temperatures after the first night contributed to bioherbicide efficacy $(29,33)$. Similar $t$ tests were used to compare daily average temperature and $\mathrm{RH}$, maximum temperature, average temperature and $\mathrm{RH}$ between 2000 and $0900 \mathrm{~h}$, and the duration of natural dew periods between the summer and fall field environments.

Plant propagation. Seeds of $A$. palmeri (from one accession collected in Hidalgo County, TX) and A. hybridus, A. retroflexus, and A. lividus (obtained from R. Charudattan, Department of Plant Pathology, University of Florida, Gainesville) were sown in 8 -cm-diameter pots (10 seeds per pot) in peat-based soil (Sunshine Mix No. 1; SunGro Horticulture, Bellevue,
WA). Seedlings were thinned to one per pot at 10 days old. Plants were maintained in a greenhouse under simulated summer conditions (temperature mean \pm SE: $29.3 \pm$ $0.1^{\circ} \mathrm{C}$; RH mean $\pm \mathrm{SE}: 73.2 \pm 0.5 \%$ ). Natural lighting was supplemented by 400W Master HPI-T Plus lamps (Philips, New York, NY) providing $490 \mu \mathrm{mol} \cdot \mathrm{m}^{-2} \cdot \mathrm{s}^{-1}$ daytime irradiance, 16:8 light/dark. Each plant was fertilized with $100 \mathrm{ml}$ of a $15.8 \mathrm{~g} /$ liter solution of 17-17-17 N-P-K fertilizer (Scotts-Sierra, Marysville, $\mathrm{OH}$ ).

Fungal propagation and inoculations. P. amaranthicola (ATCC isolate No. 74226) and $M$. amaranthi (CAB IMI isolate No. 327754) were obtained from R. Charudattan under USDA-APHIS-PPQ permits 55737 and 62145 , respectively, and were maintained at $27^{\circ} \mathrm{C}$ on a medium containing $200 \mathrm{ml}$ of tomato juice, $3 \mathrm{~g}$ $\mathrm{CaCO}_{3}$ and $15 \mathrm{~g}$ of agar $\mathrm{L}^{-1}$. Two-weekold cultures were used for preparing inoculum suspensions. In the 2003 and 2004 experiments, conidia were suspended in water containing $0.5 \% \quad(\mathrm{v} / \mathrm{v})$ polyoxyethylene sorbitan monolaurate surfactant (Tween 80; Sigma, St., Louis, MO). In the 2005 experiments, conidia were suspended in water containing $0.003 \%(\mathrm{v} / \mathrm{v})$ D-limonene and nonylphenol ethoxylate surfactant (IVOD; Brewer International, Vero Beach, FL), $0.05 \%$ (w/v) algal polysaccharide humectant (Kelgin LV; CP Kelco, San Diego, CA), and 0.2\% (v/v) Tween 80. Formulation ingredients were added during 2005 in an effort to increase symptoms and efficacy on the basis of work with other bioherbicides $(2,3,7,45,50)$. The limonene-based surfactant and the algal polysaccharide were both known to be compatible with $P$. amaranthicola germination (49). Most prior studies of both pigweed bioherbicides had used a polysaccharide humectant $(29,34,35)$. Conidial suspensions were filtered through two layers of cheesecloth and adjusted to $2 \times$ $10^{6}$ conidia $\mathrm{ml}^{-1}$ with a hemacytometer (Bright-Line; Reichert, Buffalo, NY). For combined-pathogen inoculations, suspensions were adjusted prior to mixing to yield a final concentration of $2 \times 10^{6}$ conidia $\mathrm{ml}^{-1}$ per pathogen. Fungal inoculum and controls (formulation liquid without conidia) were applied to entire plants $(3 \mathrm{ml}$ per plant) with a $150-\mathrm{ml}$ cosmetic pump sprayer (2003 and 2004 greenhouse and field studies) or a hand-held pressurized (480 kPa) 200-ml air sprayer (2005 greenhouse studies) (Ace Paint Pak 1065556; Ace Hardware, Oak Brook, IL). Plants were inoculated between 1830 and $2030 \mathrm{~h}$ and kept under plastic tents that were misted with water and then sealed for 13 $h$ after inoculation to enhance leaf wetness. This artificial dew period was provided to allow comparisons with prior studies of bioherbicides against pigweeds $(12,19,29,34,35,44)$ and other weeds $(9,13,46)$ that used similar or longer dew periods.
Comparison of pigweed species. The susceptibility of the three pigweed species to the bioherbicidal fungi was compared in a series of eight greenhouse experiments, with some experiments involving only some of the three pigweed species and four fungal treatments (control, two singlepathogen treatments, and one combinedpathogen treatment). Across seven of these experiments, 40 young A. palmeri and 51 $A$. hybridus seedlings per treatment were treated with suspensions of single pathogens or with formulation controls. In one of the eight experiments, suspensions containing both fungi were applied to a total of 13 plants of each pigweed species. In three of the eight experiments, $31 \mathrm{~A}$. retroflexus plants were inoculated with $P$. amaranthicola and 21 plants with $M$. amaranthi; no combined-pathogen inoculations of A. retroflexus were performed. Fungal suspensions were applied 18 days after seedling emergence. A. palmeri plants were $9.6 \pm 0.5 \mathrm{~cm}$ tall with $8 \pm 1$ leaves, $A$. hybridus plants were $4.9 \pm 0.2 \mathrm{~cm}$ tall with $6 \pm 0.3$ leaves, and A. retroflexus plants were $8.0 \pm 0.9 \mathrm{~cm}$ tall with $7 \pm 1$ leaves. Inoculated plants were arranged randomly within treatment groups on one greenhouse bench. The percentage of leaves on each plant with at least one necrotic lesion and the percentage of plants of each treatment that had at least one stem lesion were determined 2 weeks after inoculation. Mortality, number of new leaves (net leaf gain), and height gain were determined 3 weeks after inoculation.

Prior to statistical analysis, percent leaf necrosis data were arcsine square root transformed and leaf and height gain data were $\log$ transformed. Because leaf necrosis data were not normally distributed, leaf necrosis data were ranked across all species, treatments, and experiments for analysis. The effects of pigweed species and fungal treatment on ranked leaf necrosis, net leaf gain, and height increase were examined with ANOVA using SAS PROC MIXED with species, treatment and their interaction as fixed effects, and experiment as a random effect, followed by separate ANOVA analyses for each pigweed species to compare pathogen treatments using least-square mean comparisons with Tukey adjustment to $P$ values. This procedure did not provide an estimate of the significance of the random experiment effect. The ranges of means from individual experiments for each pathogen treatment and pigweed species are presented in the text to estimate experimental variability. Counts of plants with and without stem lesions were analyzed with asymptotic maximum-likelihood $\chi^{2}$-square tests to determine overall pigweed species and treatment effects, followed by separate analyses of treatment effects in each species. Back-transformed means of transformed necrosis data with lower and upper 95\% confidence intervals, percentages of 
plants with stem lesions, and means \pm SE's of untransformed leaf gain are presented.

Effect of plant age. In one greenhouse experiment, pigweed plants were inoculated with a combined-pathogen suspension when the plants were 35 days old and flowering. A. palmeri plants were $51.8 \pm$ $7.6 \mathrm{~cm}$ tall with $47.9 \pm 7.5$ leaves, $A$. hybridus plants were $32.1 \pm 8.7 \mathrm{~cm}$ tall with $36.3 \pm 1.6$ leaves, and $A$. retroflexus plants were $22.7 \pm 11.9 \mathrm{~cm}$ tall with $12.8 \pm 1.3$ leaves. Twelve to fourteen plants were treated per treatment per species. Three separate experiments were conducted in which 18-day-old seedlings (14 to 15 plants per pigweed species per treatment) were treated with the combined-pathogen suspension or formulation control. Leaf necrosis and stem lesions were assessed 2 weeks after inoculation. Final leaf counts and heights were measured 3 weeks after inoculation. Ranked leaf necrosis and logtransformed leaf and height data were analyzed separately for each plant age with ANOVA (with a random experiment effect for young plants) to examine species and treatment effects, followed by $t$-tests with Satterthwaite approximations to examine treatment effects for each pigweed species. Counts of plants with and without stem lesions were analyzed with asymptotic maximum-likelihood $\chi^{2}$ tests.

Field experiment with $M$. amaranthi. Three summer and two fall trials were performed in 2003 and 2004 to evaluate the efficacy of $M$. amaranthi, the only pigweed bioherbicide permitted by the USDA-APHIS for field use in south Texas, against various pigweed species. There were four blocks, except where noted, of $1-\mathrm{m}^{2}$ field plots in each experiment, each plot containing 8 to 10 seedlings of a pigweed species with one inoculated and one control plot per block. Each plot was sprayed at a rate of 680 liter ha ${ }^{-1}$ with a suspension of $M$. amaranthi or formulation control 1 week after transplanting 2-weekold greenhouse-grown pigweed seedlings Each plot received $40 \mathrm{~g}$ of fertilizer (15-912 N-P-K plus micronutrients; Osmocote; Scotts-Sierra). Plots were irrigated at transplanting and twice per week thereafter. In a summer trial (2003) that involved $A$. palmeri and A. hybridus, A. palmeri plants were $10.7 \pm 0.5 \mathrm{~cm}$ tall with $13 \pm 1$ leaves and $A$. hybridus plants were $6.0 \pm 0.3 \mathrm{~cm}$ tall with $6 \pm 0.3$ leaves. In the first fall (2003) trial with the same two pigweeds, A. palmeri plants were $29.8 \pm 4.7$ with $21.0 \pm 1.7$ leaves and A. hybridus plants were $30.8 \pm 3.4$ tall with $16.9 \pm 1.1$ leaves, while in the second fall (2004) trial, which involved a different local accession of $A$. palmeri, these plants were $18.7 \pm 1.3 \mathrm{~cm}$ tall and had $29 \pm 6$ leaves, while $A$. hybridus plants were $16.6 \pm 1.3 \mathrm{~cm}$ tall and had $30 \pm 4$ leaves. In two additional 2003 summer trials, $M$. amaranthi was applied to $A$. retroflexus $(11.1 \pm 0.4 \mathrm{~cm}$ tall, $17.2 \pm$ 0.6 leaves) and $A$. lividus L. (livid amaranth) $(4.5 \pm 0.2$ tall, $7.8 \pm 0.3$ leaves $)$ in six and four blocks of plots, respectively. Number of leaves with necrosis and number of plants with stem lesions were counted after 2 weeks. Leaf and height gain were determined after 3 weeks. All measurements involved 3 to 10 plants per pigweed species per plot. Counts of leaves with necrosis and stems with lesions were summed and divided by total leaves or plants examined to obtain one percentage value for leaf necrosis incidence and stem lesion prevalence per plot. Leaf and height gains for individual plants were averaged within plots. Species, treatment, and species $\times$ treatment effects on ranked leaf necrosis and stem lesion percentages and log-transformed leaf and height gain were analyzed separately for each experiment involving two pigweed species using ANOVA with a random block effect. Satterthwaite $t$-tests were used to analyze treatment effects for each pigweed species when the species $\times$ treatment interaction was significant or when the trial involved a single species. Back-transformed leaf necrosis and stem lesion percentages are presented with confidence intervals.

Biochemical analyses. To investigate the responses in pigweed to infection with bioherbicidal fungi, four greenhouse experiments were conducted in which four to nine plants were treated with $M$. amaranthi or $P$. amaranthicola suspension or formulation control (23 A. hybridus and $16 \mathrm{~A}$. palmeri per treatment). Samples of symptomatic leaves from inoculated plants and control leaves of the same age range (ap-
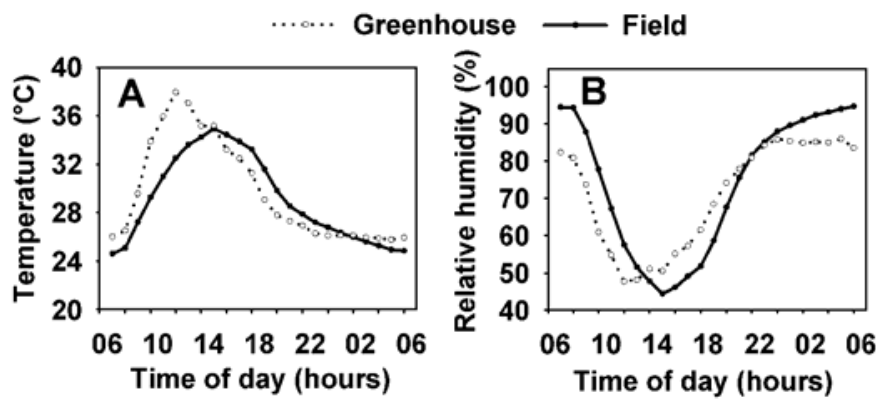

Fig. 1. Average hourly temperature (A) and relative humidity (B) over 78 days in a greenhouse used for inoculations of pigweeds with Phomopsis amaranthicola and Microsphaeropsis amaranthi and in a nearby field in the Lower Rio Grande Valley of Texas. proximately 3 to 10 positions down from the shoot tip) were collected 2 weeks after inoculation and stored at $-80^{\circ} \mathrm{C}$. Soluble protein content was determined with bovine serum albumin as a standard, and the peroxidase activity level was determined with guaiacol as a substrate as described previously for pigweed (26). Samples (0.3 g) were homogenized in $0.01 \mathrm{M}$ sodium phosphate buffer and centrifuged at 11,000 rpm for $15 \mathrm{~min}$. Soluble protein content (milligrams per gram of fresh weight) and the peroxidase activity level (change in 1 min in absorbance per gram of fresh weight) were measured spectrophotometrically at $595 \mathrm{~nm}$ and $470 \mathrm{~nm}$, respectively, using 6 and $150 \mu \mathrm{l}$ of crude extract, respectively. FAA concentrations were determined in $0.5 \mathrm{~g}$ of ground frozen leaf tissue. Because of the amount of tissue required for the assay, tissues from four plants of each species-treatment combination were pooled into a single sample from each experiment and samples from two to four experiments were used in analyses. Samples were extracted in $10 \mathrm{ml} 0.1 \mathrm{~N} \mathrm{HCl}$, centrifuged at $10,000 \mathrm{rpm}$ for $30 \mathrm{~min}$ at $4^{\circ} \mathrm{C}$, and syringe-filtered through $0.22 \mu \mathrm{m}$ of polyvinylidene diflouride (Millipore, Milford, MA). FAA (picomole per microliter) were determined by reverse-phase high-pressure liquid chromatography (26) with an Agilent 1100 Series (Agilent Technologies, Atlanta, GA). Aspartic acid, glutamic acid, serine, threonine, alanine, and valine were detected at levels sufficient for comparing treatments. Species, treatment, and random experimental effects on logtransformed protein and peroxidase levels were examined with mixed-model ANOVA with subsequent $F$-tests for treatment effect tests in each pigweed species. Untransformed FAA levels were analyzed for species and treatment effects using ANOVA. Means $( \pm$ SE) of untransformed data are presented.

\section{RESULTS}

Greenhouse and field conditions. Hourly temperatures were similar in the greenhouse and field between 3 September and 19 November in 2005 (daily average \pm $\mathrm{SE} ; 28.6 \pm 0.1^{\circ} \mathrm{C}$, greenhouse; $26.3 \pm$ $0.1^{\circ} \mathrm{C}$, field; $\left.P=0.104\right)$, while maximum daily temperatures were higher in the greenhouse $\left(37.1 \pm 0.4^{\circ} \mathrm{C}\right)$ than in the field $\left(32.3 \pm 1.1^{\circ} \mathrm{C}\right)(P<0.0001)$ (Fig. 1). Humidity was higher in the field (75.1 \pm $0.5 \%)$ than in the greenhouse $(64.2 \pm$ $0.4 \%)(P=0.031)$. In data collected from 1 September to 30 September 2005 under summer conditions, average daily greenhouse and field temperatures were similar $\left(29.7 \pm 0.2^{\circ} \mathrm{C}\right.$ and $29.1 \pm 0.2^{\circ} \mathrm{C}$ average, respectively) $(P=0.887)$. Maximum daily temperatures were higher in the greenhouse $\left(39.0 \pm 0.5^{\circ} \mathrm{C}\right)$ than in the field $(35.2 \pm$ $\left.0.5^{\circ} \mathrm{C}\right)(P<0.0001)$, while daily average $\mathrm{RH}$ was higher in the field $(74.3 \pm 0.8 \%)$ than in the greenhouse $(71.1 \pm 0.6 \%)(P<$ 
0.0001) (Fig. 1). During the hours when plants were kept under mist tents for one night (2000 to $0900 \mathrm{~h}$ ) in September 2005, ambient humidity on subsequent nights was higher in the field $(88.0 \pm 1.3 \%)$ than in the greenhouse $(82.2 \pm 1.3 \%)(P=$ $0.007)$, while temperatures were similar $\left(26.6 \pm 0.1^{\circ} \mathrm{C}\right.$ and $26.4 \pm 0.2^{\circ} \mathrm{C}$, respectively, $P=0.388$ ). There was no natural dew period $(\mathrm{RH} \geq 95 \%)$ in the greenhouse, while in the field, nightly dew periods lasted $5.1 \pm 0.8 \mathrm{~h}$.

Variation in susceptibility between pigweed species. No mortality occurred in any of the three pigweed species within 3 weeks of inoculation with either single or combined bioherbicides. P. amaranthicola and $M$. amaranthi produced punctate and veinal leaf lesions, respectively, and each produced red-brown stem lesions. Leaf necrosis varied significantly by pathogen treatment $(P<0.0001)$, pigweed species $(P$ $<0.0001)$, and the interaction of these factors $(P<0.0001)$ and inoculation led to significant leaf necrosis in two of the three species (Table 1). Across both singlepathogen treatments, necrosis incidence in A. retroflexus exceeded that in A. hybridus, which in turn exceeded that in A. palmeri $(P<0.0001)$. Inoculation with $P$. amaranthicola produced 20 and $90 \%$ more leaves with necrosis on A. hybridus and A. retroflexus, respectively, than on A. palmeri, while inoculation with $M$. amaranthi led to 26 and $92 \%$ more necrotic leaves in $A$. hybridus and $A$. retroflexus, respectively, than in A. palmeri (Table 1). Inoculation with combined pathogens did not increase leaf necrosis incidence over singlepathogen treatments. Means of leaf necrosis incidence varied widely among experiments in A. hybridus (control, 0 to $25.2 \%$; P. amaranthicola, 0 to $76.9 \%$; M. amaran- thi, 3.0 to $54.1 \%$ ) and $A$. retroflexus (control, 0 to $8.8 \%$; P. amaranthicola, 5.9 to $92.6 \%$; M. amaranthi, 10.3 to $97.3 \%$ ). In A. palmeri, means for the single-pathogen treatments and the control ranged from 0 to $10.2 \%$ leaf necrosis incidence.

The prevalence of plants with stem lesions varied significantly by pathogen treatment $(P=0.035)$ and between pigweed species $(P<0.0001)$. Stem lesions were 28 and $95 \%$ more prevalent in $A$. hybridus and $A$. retroflexus, respectively, than in A. palmeri after $P$. amaranthicola inoculation, and $54 \%$ more A. hybridus and $78 \%$ more $A$. retroflexus plants developed at least one stem lesion after M. amaranthi inoculation than $\operatorname{did} A$. palmeri (Table 1). Combined-pathogen inoculation increased stem lesion incidence by $45 \%$ in A. hybridus and $8 \%$ in A. palmeri compared with controls, but did not enhance lesion incidence over single-pathogen treatment in either species (Table 1). Stem lesion incidence varied among experiments in A. hybridus (control, 0 to 5\%; P. amaranthicola, 0 to $100 \%$; $M$. amaranthi, 0 to $100 \%$ ) and $A$. retroflexus (control, 0\%; $P$. amaranthicola, 80 to $100 \%$; M. amaranthi, 75 to $100 \%$ ), while ranging from 0 to $8 \%$ in all treatments in A. palmeri.

Leaf gain varied by pigweed species $(P<$ $0.0001)$, with control $A$. palmeri plants gaining twofold more leaves than control A. hybridus and 7.5-fold more leaves than control A. retroflexus over 3 weeks (Table 1). Leaf gain did not vary by pathogen treatment across all three species $(P=$ $0.223)$. Although the species $\times$ treatment interaction was also not significant $(P=$ 0.157 ), analysis of results for each pigweed species separately revealed that single- and combined-pathogen treatments reduced leaf gain by 24 to $36 \%$ in $A$. hy- bridus (Table 1). Leaf gain varied by experiment in A. hybridus (control, 10.8 to 37.2 leaves; $P$. amaranthicola, 6.4 to 28.2 leaves; M. amaranthi, 8.6 to 25.4 leaves), A. retroflexus (control, 0 to 39.8 leaves; $P$. amaranthicola, 0 to 44.2 leaves; $M$. amaranthi, 0 to 31.0 leaves) and $A$. palmeri (control, 23.6 to 84.8 leaves; $P$. amaranthicola, 14.6 to 76.6 leaves; M. amaranthi, 16.4 to 106.2 leaves).

Plant height gain was not influenced by treatment $(P=0.807)$ or by the treatment $\times$ species interaction $(P=0.202)$ but height gains differed between pigweed species $(P<0.0001)$. For example, height gain in A. palmeri control plants $(44.4 \pm 3.9 \mathrm{~cm})$ was considerably greater than in $A$. hybridus $(18.7 \pm 1.2 \mathrm{~cm})$ or $A$. retroflexus $(9.1 \pm 3.5 \mathrm{~cm})$ controls.

Efficacy in young and mature pigweeds. In young plants, leaf necrosis incidence varied by pathogen treatment $(P<$ $0.0001)$ and pigweed species $(P<0.0001)$ but not according to the treatment-species interaction $(P=0.088)$. Young inoculated A. hybridus and A. retroflexus plants had 11 and $13 \%$ more leaves with lesions, respectively, than did A. palmeri (Table 2). Inoculation increased leaf lesion incidence by $5 \%$ in $A$. palmeri, in contrast to the prior set of greenhouse experiments. The incidence of plants with stem lesions was influenced by treatment $(P=0.048)$ and pigweed species $(P<0.0001)$. Stem lesions occurred in inoculated $A$. hybridus and $A$. retroflexus but not in $A$. palmeri. Final leaf counts were not influenced by treatment across all three pigweed species $(P=0.487)$ but was affected by plant species $(P<0.0001)$ and the treatment $\times$ species interaction $(P=0.030)$. Three weeks after inoculation, young control $A$. palmeri plants had more leaves than $\operatorname{did} A$. hy-

Table 1. Effects of inoculation of Amaranthus palmeri (Ap), A. hybridus (Ah), and A. retroflexus (Ar) pigweeds with a single fungal pathogen (Phomopsis amaranthicola or Microsphaeropsis amaranthi) or combined pathogens

\begin{tabular}{|c|c|c|c|c|c|c|}
\hline \multirow{2}{*}{$\begin{array}{l}\text { Effect } \\
\text { Species }\end{array}$} & \multicolumn{4}{|c|}{ Inoculation treatment ${ }^{v}$} & \multirow[b]{2}{*}{$F$ or $\chi^{2}$} & \multirow[b]{2}{*}{$P$} \\
\hline & Control & P. amaranthicola & M. amaranthi & Both & & \\
\hline \multicolumn{7}{|c|}{ Leaf necrosis $(\%)^{\mathrm{w}}$} \\
\hline Ap & $0.5(0-1.3) \mathrm{a}$ & $0.6(0.1-1.6) \mathrm{a}$ & $1.4(0.4-3.0) \mathrm{a}$ & $1.3(0.1-3.7) \mathrm{a}$ & 1.38 & 0.251 \\
\hline $\mathrm{Ah}$ & $5.0(2.7-8.5) b$ & $21.0(13.6-29.9) \mathrm{a}$ & $27.9(22.2-34.2) \mathrm{a}$ & $28.5(22.9-34.6) \mathrm{a}$ & 53.8 & $<0.0001$ \\
\hline $\mathrm{Ar}$ & $1.7(0.1-5.0) b$ & $92.2(68.6-99.4) \mathrm{a}$ & $93.5(67.6-97.7) \mathrm{a}$ & $\mathrm{ND}^{\mathrm{x}}$ & 77.5 & $<0.0001$ \\
\hline \multicolumn{7}{|c|}{ Stem lesions $(\%)^{\mathrm{y}}$} \\
\hline Ap & $0 \mathrm{a}$ & $0 \mathrm{a}$ & $3 \mathrm{a}$ & $8 \mathrm{a}$ & 4.53 & 0.210 \\
\hline $\mathrm{Ah}$ & $2 b$ & $27 \mathrm{a}$ & $57 \mathrm{a}$ & $46 \mathrm{a}$ & 49.7 & $<0.0001$ \\
\hline $\mathrm{Ar}$ & $0 \mathrm{~b}$ & $95 \mathrm{a}$ & $81 \mathrm{a}$ & ND & 57.7 & $<0.0001$ \\
\hline \multicolumn{7}{|c|}{ Net leaf gain ${ }^{z}$} \\
\hline Ap & $44.8 \pm 5.3 \mathrm{a}$ & $44.1 \pm 4.8 \mathrm{a}$ & $40.6 \pm 6.1 \mathrm{a}$ & $30.2 \pm 3.5 \mathrm{a}$ & 0.88 & 0.455 \\
\hline $\mathrm{Ah}$ & $22.5 \pm 1.6 \mathrm{a}$ & $15.5 \pm 1.9 \mathrm{~b}$ & $16.6 \pm 1.4 \mathrm{~b}$ & $14.2 \pm 4.4 \mathrm{~b}$ & 4.63 & 0.004 \\
\hline $\mathrm{Ar}$ & $6.0 \pm 2.6 \mathrm{a}$ & $3.9 \pm 2.1 \mathrm{a}$ & $10.3 \pm 4.3 \mathrm{a}$ & ND & 1.70 & 0.190 \\
\hline
\end{tabular}

${ }^{\mathrm{v}}$ Results for single-pathogen and control treatments on A. palmeri and A. hybridus are means of seven experiments. Results for single-pathogen and control treatments on A. retroflexus are means of three of these experiments. One of the experiments involved combined-pathogen inoculation of A. palmeri and A. hybridus. Numbers of plants varied among species-treatment combinations and are presented in Materials and Methods.

${ }^{w}$ Percentage of leaves per plant with leaf necrosis (average with lower-upper 95\% confidence intervals). Means followed by different letters within each row are significantly different $(P=0.05)$ based on Tukey mean comparisons.

${ }^{\mathrm{x}} \mathrm{ND}=$ not determined.

${ }^{y}$ Percentage of plants per treatment with at least one stem lesion. The effect of pathogen treatment was analyzed using a likelihood-ratio $\chi^{2}$ test. A different letter following treatment and control data indicates significantly higher stem lesion incidence $(P=0.05)$ in that treatment than in the control.

${ }^{\mathrm{z}}$ Leaf gain per treatment (average $\pm \mathrm{SE}$ ). Means followed by different letters within each row are significantly different $(P=0.05)$ in Tukey mean comparisons. 
bridus and A. retroflexus (1.3- and 1.2-fold differences, respectively). A significant reduction $(32 \%)$ in leaves occurred only in inoculated $A$. hybridus (Table 2). Final heights (3 weeks after inoculation, plants were 39 days old) varied across species $(P<$ $0.0001)$, with control A. palmeri $(44.7 \pm 4.9$ $\mathrm{cm}$ ) being 1.6-fold taller than $A$. hybridus $(27.9 \pm 1.7 \mathrm{~cm})$ but statistically similar to $A$. retroflexus $(35.2 \pm 4.0 \mathrm{~cm})$. Heights were not influenced by treatment $(P=0.445)$ or the treatment $\times$ species interaction $(P=$ 0.533). Combined inoculation did not lead to mortality in young plants.

In mature plants, leaf necrosis varied between treatments $(P<0.0001)$, pigweed species $(P<0.0001)$, and their interaction $(P<0.0001)$. Inoculated $A$. hybridus and A. retroflexus plants had 27 and $89 \%$ more necrotic leaves, respectively, than did inoculated A. palmeri plants, which had only $4 \%$ more necrotic leaves than the control (Table 2). Stem lesion prevalence did not vary by treatment across all three pigweed species $(P=0.481)$ but did vary by species $(P<0.0001)$. Inoculated $A$. hybridus and $A$. retroflexus had 63 and $56 \%$ more plants with stem lesions, respectively, than $\operatorname{did} A$. palmeri, in which only $8 \%$ of inoculated plants developed one or more lesions (Table 2). Final leaf counts did not vary by treatment $(P=0.234)$ or treatment $\times$ pigweed species interaction $(P=0.105)$ but did vary by species $(P<0.0001)$. The $A$. palmeri control had twofold more leaves than A. hybridus and 3.7-fold more leaves than $A$. retroflexus. Leaf abscission negatively influenced leaf counts in all mature control plants, especially $A$. retroflexus. Leaf gain was reduced $16 \%$ by inoculation in A. hybridus (Table 2). Final heights in mature plants were significantly influenced by pigweed species $(P<0.0001)$ but not by treatment $(P=0.422)$ or treatment $\times$ species interaction $(P=0.678)$. Control $A$. palmeri plants were 1.6-fold taller than $A$. hybridus controls and 2.3-fold taller than A. retroflexus controls.
Efficacy of $M$. amaranthi in the field. Daily average temperatures were higher in the summer $\left(29.2 \pm 0.2^{\circ} \mathrm{C}\right)$ than in the fall $\left(17.5 \pm 0.6^{\circ} \mathrm{C}, P<0.001\right)$ field season, as were daily maximum temperatures $(35.4 \pm$ $0.3^{\circ} \mathrm{C}$ summer, $23.5 \pm 0.7^{\circ} \mathrm{C}$ fall, $P<$ 0.0001 ) and 2000 to $0900 \mathrm{~h}$ nighttime temperatures $\left(26.6 \pm 0.2^{\circ} \mathrm{C}\right.$ summer, 14.9 $\pm 0.6^{\circ} \mathrm{C}$ fall, $\left.P<0.0001\right)$. Daily average RH was similar between seasons $(77.7 \pm$ $0.9 \%$ summer, $73.2 \pm 0.7 \%$ fall, $P=$ $0.135)$, as was nighttime RH $(90.8 \pm 0.6 \%$ summer, $84.0 \pm 2 \%$ fall, $P=0.101)$, and the duration of natural dew periods $(7.1 \pm$ $0.5 \mathrm{~h}$ in summer, $6.8 \pm 0.7 \mathrm{~h}$ in fall, $P=$ 0.698).

In summer trial 1 (Table 3), pathogen treatment $(P=0.026)$ and pigweed species $(P<0.0001)$ influenced leaf necrosis incidence but not the treatment $\times$ species interaction $(P=0.152)$. Across both species, the incidence of necrotic leaves was not significantly higher in plots inoculated with $M$. amaranthi than in control plots, but necrosis incidence was higher on $A$. hybridus than on A. palmeri, irrespective of treatment (Table 3). The prevalence of stem lesions varied by treatment $(P=$ $0.0001)$, pigweed species $(P=0.003)$, and their interaction $(P=0.003)$. Stem lesions were $80 \%$ more prevalent in inoculated $A$. hybridus than in inoculated $A$. palmeri (Table 3 ). A. hybridus and $A$. palmeri differed in leaf and height gain $(P<0.0001$ and 0.0004 , respectively), Control A. palmeri plants gained $139 \pm$ 5.8 leaves and $81.5 \pm 4.6 \mathrm{~cm}$ in height compared with $32.2 \pm 3.4$ leaves and 30.1 $\pm 4.1 \mathrm{~cm}$ in height in A. hybridus (data not presented). Pathogen treatment did not influence leaf or height gain ( $P=$ 0.200 and 0.147 , respectively) nor did the treatment $\times$ species interaction $(P=0.194$ and 0.316).

In the first of two fall field trials involving A. palmeri and A. hybridus, pathogen treatment $(P<0.0001)$, pigweed species $(P=0.0007)$, and their interaction
$(P=0.0007)$ all influenced the incidence of necrotic leaves, while in the second trial, treatment $(P=0.001)$ and species $(P$ $=0.018)$ effects were significant but their interaction was not $(P=0.254)$. Inoculation with $M$. amaranthi significantly increased (by 6 to 17\%) the incidence of leaves with necrosis in A. hybridus over controls in both trials. Leaf necrosis incidence increased 10 to $11 \%$ after inoculation of A palmeri (Table 3 ). The prevalence of plants with stem lesions varied by pathogen treatment in both the first $(P=$ $0.019)$ and second $(P=0.004)$ fall trials, but did not vary by pigweed species $(P=$ $0.331, P=0.229$, respectively) or by the treatment $\times$ species interaction $(P=0.331$, $P=0.401$, respectively) in either trial. Inoculation increased the prevalence of $A$. hybridus plants with stem lesions by 75 and $23 \%$ in the first and second fall field trials, respectively, compared with controls. In the second trial, stem lesion prevalence increased by $64 \%$ in A. palmeri after inoculation (Table 3). Inoculation did not influence leaf gain in the first $(P=0.756)$ or second $(P=0.274)$ fall trial, nor did pigweed species $(P=0.351, P=0.873$, respectively) or the treatment $\times$ species interaction $(P=0.674, P=0.758)$ (data not presented). Height gain was marginally influenced by treatment in the first trial $(P=$ 0.051 ), with inoculated $A$. palmeri plants gaining $14 \mathrm{~cm}$ more in height than control plants, but there was no treatment effect in the second trial $(P=0.377)$, and pigweed species $(P=0.967, P=0.118)$ and the species $\times$ treatment interaction $(P=0.087$, $P=0.377)$ had no effects in either trial. In the second fall trial, control A. palmeri plants gained $13.3 \pm 3.8$ leaves and $6.0 \pm$ $3.4 \mathrm{~cm}$ in height, while A. hybridus controls gained $10.8 \pm 1.5$ leaves and $1.9 \pm 1.0$ $\mathrm{cm}$ in height.

In summer trial 2, involving A. retroflexus, control plants had 9\% more necrotic leaves than M. amaranthi-inoculated plants and no stem lesions developed in

Table 2. Effects of inoculation of young and mature Amaranthus palmeri (Ap), A. hybridus (Ah), and A. retroflexus (Ar) pigweeds with combined Phomopsis amaranthicola and Microsphaeropsis amaranthi pathogens

\begin{tabular}{|c|c|c|c|c|c|c|c|c|}
\hline \multirow{2}{*}{$\begin{array}{l}\text { Effect } \\
\text { Species }\end{array}$} & \multicolumn{4}{|c|}{ Young plants ${ }^{\mathrm{v}}$} & \multicolumn{4}{|c|}{ Mature plantsw } \\
\hline & Control & Inoculated & $T$ or $\chi^{2}$ & $\boldsymbol{P}$ & Control & Inoculated & $t$ or $\chi^{2}$ & $\boldsymbol{P}$ \\
\hline \multicolumn{9}{|c|}{ Leaf necrosis $(\%)^{\mathrm{x}}$} \\
\hline Ap & $0.2(0-2.9)$ & $4.9(2.5-8.0)$ & 3.58 & 0.001 & $0.03(0-0.04)$ & $4.2(1.1-9.4)$ & 3.89 & 0.002 \\
\hline $\mathrm{Ah}$ & $1.1(0.1-3.5)$ & $16.4(12.0-21.6)$ & 6.30 & $<0.0001$ & $1.4(0.2-3.5)$ & $32.8(29.1-36.6)$ & 9.27 & $<0.0001$ \\
\hline $\mathrm{Ar}$ & $1.5(0.1-4.7)$ & $18.2(12.9-24.2)$ & 6.03 & $<0.0001$ & $0.4(0.0-2.3)$ & $92.5(80.7-99.3)$ & 13.6 & $<0.0001$ \\
\hline \multicolumn{9}{|c|}{ Stem lesions $(\%)^{\mathrm{y}}$} \\
\hline Ap & 0 & 0 & $\ldots$ & $\ldots$ & 0 & 8 & 1.51 & 0.219 \\
\hline $\mathrm{Ah}$ & 0 & 60 & 16.5 & $<0.0001$ & 7 & 71 & 13.6 & 0.0002 \\
\hline $\mathrm{Ar}$ & 0 & 27 & 6.16 & 0.013 & 0 & 64 & 16.1 & $<0.0001$ \\
\hline \multicolumn{9}{|c|}{ Number of leaves ${ }^{\mathrm{Z}}$} \\
\hline Ap & $37.7 \pm 3.9$ & $50.1 \pm 7.5$ & 1.27 & 0.216 & $47.8 \pm 7.5$ & $60.3 \pm 8.0$ & 1.07 & 0.295 \\
\hline $\mathrm{Ah}$ & $29.7 \pm 2.2$ & $22.3 \pm 2.6$ & 2.27 & 0.032 & $36.3 \pm 1.6$ & $30.6 \pm 1.7$ & 2.42 & 0.023 \\
\hline $\mathrm{Ar}$ & $32.9 \pm 3.9$ & $30.8 \pm 3.6$ & 0.20 & 0.841 & $12.8 \pm 1.2$ & $16.3 \pm 1.2$ & 1.87 & 0.073 \\
\hline
\end{tabular}

${ }^{\mathrm{v}}$ Results are means of three experiments on young (18-day-old) plants.

${ }^{w}$ Results from one experiment on mature (35-day-old) plants.

${ }^{x}$ Percentage of leaves per plant with leaf necrosis (average with lower-upper $95 \%$ confidence intervals). $T$-tests were used to analyze treatment effects.

y Percentage of plants per treatment with at least one stem lesion. The effect of pathogen treatment was examined with a likelihood-ratio $\chi^{2}$ test.

${ }^{\mathrm{z}}$ Final leaf counts (average $\pm \mathrm{SE}$ ). $T$-tests were used to analyze treatment effects. 
response to $M$. amaranthi (Table 3 ). In summer trial 3 on A. lividus, inoculation did not increase leaf necrosis incidence, but most plants in the inoculated plots developed stem lesions (Table 3). Inoculation with $M$. amaranthi did not influence leaf or height gain in either of these two experiments $(P>0.05)$.

Biochemical responses to inoculation. Protein content in A. hybridus and $A$. palmeri varied marginally in response to inoculation with $P$. amaranthicola or $M$. amaranthi $(P=0.069)$ and protein content was $18 \%$ lower in $M$. amaranthiinoculated $A$. palmeri than in control plants (Table 4), but protein content did not vary between pigweed species $(P=$ $0.430)$. Means for protein content, measured as milligrams per gram of fresh weight, varied across experiments for $A$. palmeri (control, 8.3 to 11.3 ; P. amaranthicola, 6.8 to $13.7 ;$ M. amaranthi, 5.1 to 11.7) and A. hybridus (control, 6.3 to 14.5 ; P. amaranthicola, 9.2 to $11.9 ;$ M. amaranthi, 7.8 to 9.8$)$. The peroxidase activity level varied by pathogen treatment $(P=$ 0.048) and species $(P<0.0001)$. P amaranthicola increased the soluble peroxidase activity level 1.8 -fold in A. palmeri (Table 4), while neither of the two patho- gens influenced the soluble peroxidase activity level in A. hybridus. The range of means for peroxidase (change in absorbance per gram of fresh weight in $1 \mathrm{~min}$ ) across experiments were: A. palmeri, control, 3.2 to $35.1 ;$ P. amaranthicola, 5.6 to 97.7; M. amaranthi, 9.4 to 34.7 ; and in $A$. hybridus, control, 4.3 to 25.4 ; $P$. amaranthicola, 5.0 to $32.3 ;$ M. amaranthi, 6.2 to 21.4. Neither aspartic nor glutamic acid FAA levels varied by treatment $(P=0.554$, $P=0.882$, respectively) or treatment $\times$ species interaction $(P=0.391, P=0.785)$, but both varied by species. Aspartic acid was 2.5 -fold greater in $A$. hybridus $(P=$

Table 3. Effects of inoculation of Amaranthus palmeri (Ap), A. hybridus (Ah), A. retroflexus (Ar), and A. lividus (Al) pigweeds with Microsphaeropsis amaranthi in summer and fall field plot experiments ${ }^{\mathrm{w}}$

\begin{tabular}{|c|c|c|c|c|c|c|}
\hline Trial & Effect & Species & Control & M. amaranthi & $t$ & $P$ \\
\hline \multicolumn{7}{|c|}{ Summer trials } \\
\hline \multirow[t]{5}{*}{1} & $\begin{array}{l}\text { Leaf necrosis } \\
(\%)^{\mathrm{x}}\end{array}$ & Ap & $0.2(0.1-1.7)$ & $2.8(1.0-5.5)$ & $\ldots^{y}$ & $\cdots$ \\
\hline & & $\mathrm{Ah}$ & $17.2(7.5-30.7)$ & $25.8(6.5-55.6)$ & . & \\
\hline & & Mean & $5.3(0.3-16.4)$ & $11.5(2.7-26.5)$ & 1.05 & 0.311 \\
\hline & Stem lesions $(\%)^{\mathrm{z}}$ & Ap & 0 & $1.7(0-29.5)$ & 1.00 & 0.391 \\
\hline & & $\mathrm{Ah}$ & 0 & $82.1(7.3-100)$ & 11.2 & 0.002 \\
\hline \multirow[t]{2}{*}{2} & Leaf necrosis $(\%)$ & $\mathrm{Ar}$ & $15.9(8.1-26.2)$ & $6.4(1.1-16.0)$ & 2.52 & 0.032 \\
\hline & Stem lesions (\%) & $\mathrm{Ar}$ & 0 & 0 & $\ldots$ & $\ldots$ \\
\hline \multirow[t]{2}{*}{3} & Leaf necrosis (\%) & $\mathrm{Al}$ & $1.4(0.2-3.5)$ & $0.5(0-2.3)$ & 1.59 & 0.170 \\
\hline & Stem lesions (\%) & $\mathrm{Al}$ & 0 & $99.7(51.7-100)$ & 6.53 & 0.007 \\
\hline \multicolumn{7}{|c|}{ Fall trials } \\
\hline \multirow[t]{5}{*}{1} & Leaf necrosis $(\%)$ & Ap & 0 & $10.3(7.4-13.7)$ & 9.30 & 0.0001 \\
\hline & & $\mathrm{Ah}$ & 0 & $17.3(13.6-21.5)$ & 15.5 & $<0.0001$ \\
\hline & Stem lesions (\%) & Ap & $2.3(0-40.2)$ & $5.7(0-83.9)$ & $\ldots$ & $\ldots$ \\
\hline & & $\mathrm{Ah}$ & $2.3(0-40.2)$ & $76.9(4.8-100)$ & & \\
\hline & & Mean & $2.4(0.7-15.3)$ & $45.5(6.4-95.1)$ & 2.70 & 0.020 \\
\hline \multirow[t]{6}{*}{2} & Leaf necrosis (\%) & Ap & 0 & $11.9(3.5-20.9)$ & $\ldots$ & $\ldots$ \\
\hline & & $\mathrm{Ah}$ & $9.5(6.9-12.5)$ & $15.3(8.4-24.3)$ & & \\
\hline & & Mean & $2.4(0-8.6)$ & $13.6(9.8-18.0)$ & 3.50 & 0.004 \\
\hline & Stem lesions (\%) & Ap & $2.4(0-40.2)$ & $66.5(0-100)$ & $\ldots$ & $\ldots$ \\
\hline & & $\mathrm{Ah}$ & $34.0(14.4-59.4)$ & $57.8(20.0-95.4)$ & $\ldots$ & $\ldots$ \\
\hline & & Mean & $13.8(1.1-39.6)$ & $62.2(27.8-94.1)$ & 2.96 & 0.011 \\
\hline
\end{tabular}

${ }^{\text {w }}$ All trials involved four blocks except for summer trial 2, which involved six blocks.

${ }^{x}$ Percentage of leaves per plot with leaf necrosis (average with lower-upper 95\% confidence intervals).

y ... Denotes omission of a $t$-test and $P$ determination for the treatment effect because the treatment $\times$ species interaction was not significant except for stem lesions in summer trial 2, in which no statistical test could be run.

${ }^{\mathrm{z}}$ Percentage of plants per plot with at least one stem lesion (average with lower-upper 95\% confidence intervals).

Table 4. Effects of inoculation of Amaranthus palmeri (Ap) and A. hybridus (Ah) with Phomopsis amaranthicola or Microsphaeropsis amaranthi on protein content, peroxidase activity level, and aspartic and glutamic free amino acid content

\begin{tabular}{|c|c|c|c|c|c|c|}
\hline & Species & Control & P. amaranthicola & M. amaranthi & $F$ & $P$ \\
\hline Protein $^{x}$ & $\begin{array}{l}\text { Ap } \\
\text { Ah }\end{array}$ & $\begin{array}{l}9.57 \pm 0.55 \mathrm{a} \\
8.55 \pm 0.89 \mathrm{a}\end{array}$ & $\begin{array}{l}9.76 \pm 1.00 \mathrm{a} \\
10.7 \pm 0.77 \mathrm{a}\end{array}$ & $\begin{array}{l}7.82 \pm 0.80 \mathrm{~b} \\
9.04 \pm 0.42 \mathrm{a}\end{array}$ & $\begin{array}{l}3.73 \\
2.24\end{array}$ & $\begin{array}{l}0.033 \\
0.116\end{array}$ \\
\hline Peroxidase $^{y}$ & $\begin{array}{l}\text { Ap } \\
\text { Ah }\end{array}$ & $\begin{array}{l}27.0 \pm 5.33 \mathrm{~b} \\
15.1 \pm 3.58 \mathrm{a}\end{array}$ & $\begin{array}{l}49.1 \pm 13.8 \mathrm{a} \\
20.6 \pm 4.38 \mathrm{a}\end{array}$ & $\begin{array}{l}28.2 \pm 4.24 \mathrm{~b} \\
12.8 \pm 2.47 \mathrm{a}\end{array}$ & $\begin{array}{l}3.24 \\
0.57\end{array}$ & $\begin{array}{l}0.049 \\
0.570\end{array}$ \\
\hline Aspartic acidz & $\begin{array}{l}\text { Ap } \\
\text { Ah }\end{array}$ & $\begin{array}{l}307 \pm 87 \mathrm{a} \\
774 \pm 99 \mathrm{a}\end{array}$ & $\begin{array}{l}339 \pm 94 \mathrm{a} \\
586 \pm 175 \mathrm{a}\end{array}$ & $\begin{array}{l}526 \pm 13 \mathrm{a} \\
668 \pm 112 \mathrm{a}\end{array}$ & $\begin{array}{l}1.61 \\
0.56\end{array}$ & $\begin{array}{l}0.289 \\
0.595\end{array}$ \\
\hline Glutamic acid ${ }^{\mathrm{z}}$ & $\begin{array}{l}\text { Ap } \\
\text { Ah }\end{array}$ & $\begin{array}{r}1,002 \pm 63 \mathrm{a} \\
450 \pm 162 \mathrm{a}\end{array}$ & $\begin{array}{r}1,216 \pm 256 \mathrm{a} \\
463 \pm 164 \mathrm{a}\end{array}$ & $\begin{array}{r}1,014 \pm 88 \mathrm{a} \\
619 \pm 352 \mathrm{a}\end{array}$ & $\begin{array}{l}0.47 \\
0.14\end{array}$ & $\begin{array}{l}0.649 \\
0.872\end{array}$ \\
\hline
\end{tabular}

${ }^{\mathrm{x}}$ Soluble protein content (average $\pm \mathrm{SE}$ ) as milligrams per gram of fresh weight. Results are means of four greenhouse experiments. Means followed by different letters within each row are significantly different $(P \leq 0.05)$ in Tukey mean comparisons.

${ }^{y}$ Soluble peroxidase activity level (average \pm SE) as the change in absorbance in 1 min per gram of fresh weight. Results are means of four greenhouse experiments. Means followed by different letters within each row are significantly different $(P \leq 0.05)$ in Tukey mean comparisons.

${ }^{\mathrm{z}}$ Free amino acid content (average $\pm \mathrm{SE}$ ) as picomoles per microliter. Results are means of two to four samples per treatment per species. Each sample was a pool of leaf tissue from one experiment. 
$0.011)$ and glutamic acid was 2.2-fold greater in A. palmeri $(P=0.015)$. Inoculation did not influence concentrations of alanine, serine, threonine, and valine (data not presented).

\section{DISCUSSION}

Greenhouse conditions for inoculations with pigweed bioherbicides reflected summer field conditions in south Texas. However, the higher maximum daily temperatures, lower average humidity, and absence of a 'natural' dew period may have made greenhouse conditions more limiting to infection than those in the field. In neither environment were pigweeds killed by inoculation with $P$. amaranthicola, $M$. amaranthi, or combined pathogens, which is in contrast to past studies $(29,33,35)$. Average greenhouse and summer field temperatures were 2 to $9^{\circ} \mathrm{C}$ higher and ambient humidity as much as $10 \%$ lower in this study than in some prior field studies, $(29,33,44)$. Comparisons of temperature and rainfall data from Weslaco, TX (28) with data from previous testing locations (Gainesville, FL and Urbana, IL) support the conclusion that ambient temperatures were higher and the humidity lower in south Texas.

Germination and initial penetration by conidia of both fungi occur between $15^{\circ} \mathrm{C}$ (M. amaranthi) or $20^{\circ} \mathrm{C}$ (P. amaranthicola) and $30^{\circ} \mathrm{C}(30,44)$. The infection process takes at least $15 \mathrm{~h}$ and is not always complete by $24 \mathrm{~h}$ (30). In greenhouse and field experiments in this study, temperature conditions during the first $13 \mathrm{~h}$ after inoculation, when plants were under the mist tents, were compatible with conidial germination and germ tube elongation of both pathogens on leaf surfaces (30), although high compared with some past studies on M. amaranthi (44). The 13-h dew period used in this study was sufficient to produce mortality in other studies on $P$. amaranthicola (35), M. amaranthi (44), and on other pigweed pathogens $(12,19)$. Similar dew periods (10 to $15 \mathrm{~h}$ ) were used in bioherbicide trials on waterhyacinth (Eichhornia crassipes Solms-Laubach), kudzu (Pueraria montana [Lour.] Merr. var. lobata [Willd.] Massen \& S.M. Almeida), and dandelion (Taraxacum officinale Weber $(7,9,13,37,38,40,50)$. The relatively low incidence of disease and lack of mortality observed in greenhouse experiments were thus likely related to high maximum temperatures and variable, at times low, humidity that occurred after the dew period. $(29,33)$. The role of environmental limitations in this study was therefore restricted to events occurring after fungal penetration. The incidence of leaf necrosis and stem lesions would have likely been still lower in the absence of the artificially imposed initial dew period. Improved formulations, containing oils and other ingredients in addition to or in place of the surfactant and humectant used in this study, could decrease humidity requirements and increase mortality on pigweeds $(15,23,25)$, as in other bioherbicide systems $(2,3,7,19$, $37,40,45,50)$.

In greenhouse experiments, despite a wide degree of variation in symptom incidence between experiments, A. retroflexus and $A$. hybridus showed greater susceptibility to infection by $P$. amaranthicola and $M$. amaranthi than $\operatorname{did} A$. palmeri. Net leaf gain was reduced only in A. hybridus, likely due to leaf abscission (29), while gains in shoot height were never negatively affected. Inoculation with combined pathogens did not specifically increase symptom incidence over single-pathogen treatment, in agreement with past symptom and mortality results for these two bioherbicides (29). Our results corroborate initial work on $M$. amaranthi, which characterized $A$. palmeri, at the four- to six-leaf stage, as resistant and $A$. hybridus and $A$. retroflexus as susceptible (24). In testing $P$. amaranthicola, Rosskopf et al. (34) placed most of the $A$. retroflexus and $A$. hybridus accessions they tested in higher mortality classes than A. palmeri. Ortiz-Ribbing and Williams (29) reported more severe effects of $P$. amaranthicola on biomass and mortality in A. hybridus than in A. palmeri in the field, but also demonstrated the ability of $M$. amaranthi and combined-pathogen application in Illinois to kill all three of the Amaranthus spp. tested in south Texas in this study. Conidial germination of P. amaranthicola and $M$. amaranthi were similar on the three pigweed species, and germ tube elongation was actually greatest on $A$. palmeri (30). Interspecific variation in resistance can emerge in later stages of the infection process $(4,21)$. Symptom incidence, but not symptom development (i.e., leaf area exhibiting symptoms over time), were measured in this study, and so the roles of resistance in influencing pre- versus post-penetration events and subsequent symptom levels are not clear. The fast growth of $A$. palmeri, as evidenced in this study by higher net leaf and shoot height gains in A. palmeri control plants than in controls of the other Amaranthus spp., could have allowed A. palmeri to tolerate infection, further reducing the efficacy of the two bioherbicides against this regionally dominant pigweed species.

The incidence of leaf necrosis and stem lesions in this study in relatively susceptible A. hybridus was below levels reported in earlier studies $(29,33,35)$. Some previous studies allowed more time (5 to 8 weeks) to assess disease development and mortality, although 15 days was sufficient for mortality to occur in all three pigweed species in one study (29). Weed age has been reported to be a critical factor in determining the efficacy of fungal bioherbicides, with mortality being highest in young (one- to six-leaf) plants (15), typically used in studies of $P$. amaranthicola and $M$. amaranthi $(29,33,34,44,45)$ and Alternaria alternata (Fr.) Keissler $(12,19)$ on Amaranthus spp. Rosskopf et al. (35) reported as much as $100 \%$ mortality 8 weeks after $P$. amaranthicola inoculation of four- to six-leaf $A$. hybridus incubated for $8 \mathrm{~h}$ at a dew temperature of $35^{\circ} \mathrm{C}$ and then maintained in a greenhouse averaging $35^{\circ} \mathrm{C}$ during the day. Plant age may thus be as important as environmental conditions in limiting efficacy. The young plants used in this study were large relative to past studies, having 4 to 10 leaves in greenhouse and summer field experiments and as many as 30 leaves in fall field experiments. Only one greenhouse experiment was conducted with mature plants and young plants were tested separately. Nonetheless, the results suggest that young and mature (35-day-old) plants of A. hybridus and $A$. retroflexus exhibited roughly similar disease incidence levels that in both cases exceeded levels on $A$. palmeri plants of comparable ages. The modest negative effect on A. hybridus leaf counts was also common to both ages. Our results suggest that sublethal disease incidence after $P$. amaranthicola and M. amaranthi inoculation is affected less by weed age than by interspecific differences in susceptibility. Symptom development on mature $A$. hybridus and $A$. retroflexus could contribute to weed management in the field if mature infected plants act as inoculum reservoirs for nearby seedlings or if infection of mature, flowering plants reduces reproduction.

Average summer and fall temperatures and humidity in the field were likely suitable for fungal infection, but, as in the comparisons of greenhouse with field environments, environmental extremes (maximum temperatures in the summer, minimums in the fall) may have been more important than averages. In the fall field trial, low temperatures (below $15^{\circ} \mathrm{C}$ ) during the dew period and on subsequent nights could have limited symptom incidence in plants infected with $M$. amaranthi $(35,44)$. In one summer field trial and in the first fall field trial with $M$. amaranthi, inoculated $A$. hybridus plants showed symptom incidence levels similar to those observed in the greenhouse. However, abiotic (wind, sand) or biotic (insects) damage may have obscured inoculation effects on A. hybridus in the summer trial and in the second fall trial. The high incidence of stem lesions in inoculated $A$. palmeri in the second fall field trial may have been related to the use of a separate accession for this trial. Leaf and height gain were not greater in A. palmeri than in A hybridus in the two fall trials, in contrast to the results from greenhouse experiments and summer field trials. Reduced fall growth may have increased leaf necrosis symptom incidence on $A$. palmeri. The lack of symptoms in A. retroflexus in one summer trial are suggestive of a procedural error, such as mist tent failure, rather than environmental constraints since inocula- 
tion increased leaf and stem necrosis incidence in $A$. hybridus under similar field conditions and in $A$ retroflexus in the greenhouse. The increase in stem lesion incidence, though not leaf necrosis, in $A$. lividus is consistent with the known susceptibility of this species to $M$. amaranthi (23), and A. lividus can also be killed by $P$. amaranthicola $(29,34)$.

Low symptom incidence in A. palmeri after $P$. amaranthicola inoculation may have been related to peroxidase induction, a common response to pathogen infection $(21,47)$. The herbicide bentazon increased dry mass losses in velvetleaf (Abutilon theophrasti Medik) inoculated with Colletotrichum coccodes (Wallr.) Hughes (1), in part by suppressing peroxidase induction by twofold. Bentazon is compatible with $P$. amaranthicola germination and growth (49) and could reduce the twofold peroxidase induction that occurred in A. palmeri, potentially leading to greater symptom development in response to $P$. amaranthicola. Other bioherbicide-chemical herbicide combinations could increase the efficacy of $M$. amaranthi (45), as in other bioherbicide systems (38).

Protein and FAA content are commonly altered by fungal infection (16), possibly affecting feeding and growth of pest insects (48). The beet armyworm (Spodoptera exigua Hübner), a pest of cotton, uses pigweeds as hosts $(26,41)$ and might show different feeding patterns on M. amaranthi-infected and healthy $A$. palmeri because of reductions in soluble protein after inoculation. Changes in FAA accumulations in pigweeds (26) and other plants $(27,42,43)$ are associated with plant stresses, including water deficit and infection by pathogens. The stability of the six FAA detected in our study suggests that $P$. amaranthicola and $M$. amaranthi infection do not induce water deficit stress responses in pigweeds. However, environmental factors, plant phenology, interspecific resistance variation, and physiochemical induction all influence the efficacy of these two pathogens on Amaranthus spp.

\section{ACKNOWLEDGMENTS}

We thank R. Charudattan and J. DeValerio, Department of Plant Pathology, University of Florida, Gainesville, FL for providing pathogen cultures and pigweed seed; C. Graham, M. Leal, and J. Cavazos for technical assistance; S. Duke for statistical advice; and S. Hallett, E. Rosskopf, and two anonymous reviewers. P. amaranthicola was obtained under a Materials Transfer Agreement with the University of Florida. Mention of trade names or commercial products in this article is solely for the purpose of providing information and does not imply recommendation or endorsement by the U.S. Department of Agriculture.

\section{LITERATURE CITED}

1. Ahn, B., Paulitz, T., Jabaji-Hare, S., and Watson, A. 2005. Enzyme responses of Abutilon theophrasti in an enhanced biocontrol system. BioControl 50:803-817.

2. Auld, B. A., Hetherington, S. D., and Smith, H. E. 2003. Advances in bioherbicide formulation. Weed Biol. Manag. 3:61-67.
3. Bailey, B. A., O'Neill, N. R., and Anderson, J. D. 2004. Influence of adjuvants on disease development by Pleospora papaveracea on opium poppy (Papaver somniferum). Weed Sci. 52:424-432.

4. Barton, J. 2004. How good are we at predicting the field host rage of fungal pathogens used for classical biological control of weeds? Biol. Control 31:99-122.

5. Beckie, H. J., and Gill, G. S. 2006. Strategies for managing herbicide-resistant weeds. Pages 581-625 in: Handbook of Sustainable Weed Management. H. Pal Singh, D. R. Batish, and R. K. Kohli, eds. Food Products Press, New York.

6. Birschbach, E. D., Myers, M. G., and Harvey, R. G. 1993. Triazine-resistant smooth pigweed (Amaranthus hybridus) control in field corn (Zea mays L.). Weed Technol. 7:431-436.

7. Boyette, C. D., Walker, H. L., and Abbas, H. K. 2002. Biological control of kudzu (Pueraria lobata) with an isolate of Myrothecium verrucaria. Biocontrol Sci. Technol. 12:75-82.

8. Bürki, H.-M., Schroeder, D., Lawrie, J., Cagan, L., Vrablova, M., El Aydam, M., Szentkiraly, F., Ghorbani, R., Juttersonke, B., and Ammon, H. U. 1997. Biological control of pigweeds (Amaranthus retroflexus L., A. powelli S. Watson and A. bouchonii Thell.) with phytophagous insects, fungal pathogens and crop management. Integrated Pest Manag. Rev. 2:51-59.

9. Chandramohan, S., and Charudattan, R. 2003. A multiple-pathogen system for bioherbicidal control of several weeds. Biocontrol Sci. Technol. 13:199-205.

10. Charudattan, R. 2001. Biological control of weeds by means of plant pathogens: Significance for integrated weed management in modern agro-ecology. BioControl 46:229-260.

11. Charudattan, R. 2005. Ecological, practical, and political inputs into selection of weed targets: What makes a good biological control agent? Biol. Control 35:183-196.

12. Ghorbani, R., Seel, W., Litterick, A., and Leifert, C. 2000. Evaluation of Alternaria alternata for biological control of Amaranthus retroflexus. Weed Sci. 48:474-480.

13. Graham, G. L., Peng, G., Bailey, K. L., and Holm, F. A. 2006. Effect of dew temperature, post-inoculation condition, and pathogen dose on suppression of scentless chamomile by $\mathrm{Col}$ letotrichum truncatum. Biocontrol Sci. Technol. 16:271-280.

14. Griffith, G. M., Barrentine, J., and McClelland, M. R. 2006. Weed competition effects in Roundup Ready Flex cotton (Gossypium hirsutum L.). Pages 2277-2280 in: Proc. 2006 Beltwide Cotton Conf. National Cotton Council, Memphis.

15. Hallett, S. G. 2005. Where are the bioherbicides? Weed Sci. 53:404-415.

16. Hatcher, P. E. 1995. Three-way interactions between plant pathogenic fungi, herbivorous insects and their host plants. Biol. Rev. 70:639694.

17. Heap, I. 2005. The International Survey of Herbicide-Resistant Weeds. Herbicide-Resistant Plant Committee, Weed Science Society of America. Online publication.

18. Kropff, M. J., Weaver, S. E., and Smits, M. A. 1992. Use of ecophysical models for cropweed interference: Relations amongst weed density, relative time of weed emergence, relative leaf area, and yield loss. Weed Sci. 40:296-301.

19. Lawrie, J., Down, V. M., and Greaves, M. P. 2000. Factors influencing the efficacy of the potential herbicide Alternaria alternata (Fr.) Keissler on Amaranthus retroflexus (L). Biocontrol Sci Technol. 10:81-87.

20. Manley, B. S., Singh, B. K., Shaner, D. L., and Wilson, H. P. 1999. Imidazolinone resistance in smooth pigweed (Amaranthus hybridus) is due to an altered acetolactate synthase. Weed Technol. 13:697-705.

21. Maor, R., and Sharasu, K. 2005. The arms race continues: Battle strategies between plants and fungal pathogens. Curr. Opin. Microbiol. 8:399-404.

22. McNaughton, K. E., Letarte, J., Lee, E. A., and Tardif, F. J. 2005. Mutations in ALS confer herbicide resistance in redroot pigweed (Amaranthus retroflexus) and Powell amaranth (Amaranthus powellii). Weed Sci. 53:17-22.

23. Mintz, A. S. 1991. Evaluation of Aposphaeria amaranthi as a potential mycoherbicide for Amaranthus spp. M.S. thesis. University of Arkansas, Fayetteville.

24. Mintz, A. S., Heiny, D. K., and Weidemann, G. J. 1992. Factors influencing the biocontrol of tumble pigweed (Amaranthus albus) with Aposphearia amaranthi. Plant Dis. 76:267-269.

25. Morales-Payan, J. P., Stall, W., Charudattan, R., and DeValerio, J. T. 2003. Competitiveness of livid amaranth (Amaranthus lividus) with basil (Ocimum basilicum) as affected by Phomopsis amaranthicola applied with different surfactants. Hortscience (abstract) 38:700.

26. Moran, P. J., and Showler, A. T. 2005. Plant responses to water deficit and shade stresses in pigweed and their influence on feeding and oviposition by the beet armyworm. Environ. Entomol. 34:929-937.

27. Nemec, S. 1995. Stress-related compounds in xylem fluid of blight-diseased citrus containing Fusarium solani naphthazarin toxins and their effects on the host. Can. J. Microbiol. 41:515-524.

28. NOAA. 2005. Climatography of the United States. No. 20, 1971-2000. National Oceanic and Atmospheric Administration, National Climatic Data Center, Asheville, NC.

29. Ortiz-Ribbing, L., and Williams, M. M. II. 2006. Potential of Phomopsis amaranthicola and Microsphaeropsis amaranthi as bioherbicides for several weedy Amaranthus species. Crop Prot. 25:39-46.

30. Ortiz-Ribbing, L., and Williams, M. M. II 2006. Conidial germination and germ tube elongation of Phomopsis amaranthicola and Microsphaeropsis amaranthi on leaf surfaces of seven Amaranthus species: Implications for biological control. Biol. Control 38:356-362.

31. Qiang, S., Zhu, Y., Summerell, B. A., and Li, Y. 2006. Mycelium of Alternaria alternata as a potential biological control agent for Eupatorium adenophorum. Biocontrol Sci. Technol. 16:653-688.

32. Richardson, A. 1995. Pages 66-70 in: Plants of the Rio Grande Delta. University of Texas Press, Austin.

33. Rosskopf, E. N., Charudattan, R., DeValerio, J. T., and Stall, W. M. 2000. Field evaluation of Phomopsis amaranthicola, a biological control agent of Amaranthus spp. Plant Dis. 84:12251230.

34. Rosskopf, E. N., Yandoc, C. B., and Charudattan, R. 2006. Genus-specific host range of Phomopsis amaranthicola (Sphaeropsidales), a bioherbicide agent for Amaranthus spp. Biocontrol Sci. Technol. 16:27-35.

35. Rosskopf, E. N., Yandoc, C. B., Charudattan, R., and DeValerio, J. T. 2005. Influence of epidemiological factors on the bioherbicidal efficacy of P. amaranthicola on Amaranthus hybridus. Plant Dis. 89: 1295-1300.

36. Rowland, M. W., Murray, D. S., and Verhalen, L. M. 1999. Full-season Palmer amaranth (Amaranthus palmeri) interference with cotton (Gossypium hirsutum). Weed Sci. 47:305-309.

37. Sandrin, T. R., TeBeest, D. O., and Weidemann, G. J. 2003. Soybean and sunflower oils increase the infectivity of Colletotichum gloeosporioides $\mathrm{f}$. sp. aeschynomene to northern jointvetch. Biol. Control 26:244-252.

38. Schnick, P. J., and Boland, G. J. 2004. 2,4-D and Phoma herbarum to control dandelion 
(Taraxacum officinale). Weed Sci. 52:808-814.

39. Sellers, B. A., Smeda, R. J., Johnson, W. G., Kendig, J. A., and Ellersieck, M. R. 2003. Comparative growth of six Amaranthus species in Missouri. Weed Sci. 51:329-333.

40. Shabana, Y. M. 2005. The use of oil emulsions for improving the efficacy of Alternaria eichhorniae as a mycoherbicide for waterhyacinth (Eichhornia crassipes). Biol. Control 32:7889.

41. Showler, A. T. 2001. Spodoptera exigua oviposition and larval feeding preferences for pigweed, Amaranthus hybridus over squaring cotton, Gossypium hirsutum, and a comparison of free amino acids in each host plant. J. Chem. Ecol. 27:2013-2028.

42. Showler, A. T. 2002. Effects of water deficit and stress, shade, weed competition, and kaolin particle film on selected foliar free amino acid accumulations in cotton, Gossypium hir- sutum L. J. Chem Ecol. 28:631-651.

43. Showler, A. T., Reagan, T. E., and Shao, K. P. 1990. Nematode interactions with weeds and sugarcane mosaic virus in Louisiana sugarcane. J. Nematol. 22:31-38.

44. Smith, D. A., Doll, D. A., Singh, D., and Hallett, S. G. 2006. Climatic constraints to the potential of Microscphaeropsis amaranthi as a bioherbicide for common waterhemp. Phytopathology 96:308-312.

45. Smith, D. A., and Hallett, S. G. 2006. Interactions between chemical herbicides and the candidate bioherbicide Microsphaeropsis amaranthi. Weed Sci. 54:532-537.

46. Stewart-Wade, S. M., and Boland, G. J. 2004. Selected cultural and environmental parameters influence disease severity of dandelion caused by the potential bioherbicidal fungi, Phoma herbarum and Phoma exigua. Biocontrol Sci. Technol. 14:561-569.
47. van Loon, L. C., Rep, M., and Pieterse, C. M. J. 2006. Significance of inducible defense-related proteins in infected plants. Annu. Rev. Phytopathol. 44:135-162.

48. Waring, G. L., and Cobb, N. S. 1992. The impact of plant stress on herbivore population dynamics. Pages 167-226 in: Insect-Plant Interactions. Vol. 4. E. A. Bernays, ed. CRC Press, Boca Raton, FL.

49. Wyss, G. S., Charudattan, R., Rosskopf, E. N., and Littell, R. C. 2004. Effects of selected pesticides and adjuvants on germination and vegetative growth of Phomopsis amaranthicola, a biocontrol agent for Amaranthus spp. Weed Res. 44:469-482.

50. Zhang, W., Wolf, T. M., Bailey, K. L., Mortensen, K., and Boyetchko, S. M. 2003. Screening of adjuvants for bioherbicide formulations with Colletotrichum spp. and Phoma spp. Biol. Control 26:95-108. 